\title{
Combination treatment with arsenic trioxide and sulindac augments their apoptotic potential in lung cancer cells through activation of caspase cascade and mitochondrial dysfunction
}

\author{
HAK-RYUL KIM ${ }^{1}$, EUN-JUNG KIM ${ }^{2}$, SEI-HOON YANG ${ }^{1}$, EUN-TAIK JEONG ${ }^{1}$, CHANNY PARK $^{2}$, \\ SE-JIN KIM ${ }^{2}$, MYUNG-JA YOUN ${ }^{2}$, HONG-SEOB SO ${ }^{2}$ and RAEKIL PARK ${ }^{2}$ \\ Departments of ${ }^{1}$ Internal Medicine and ${ }^{2}$ Microbiology, Wonkwang University, \\ School of Medicine, 344-2 Shinyong-dong Iksan, Jeonbuk 570-749, South Korea
}

Received January 10, 2006; Accepted March 2, 2006

\begin{abstract}
Non-steroidal anti-inflammatory drugs (NSAIDs) are known to enhance the responsiveness of tumor cells toward chemotherapeutic drugs and radiation. However, the precise mechanism of synergistic enhancement in tumoricidal activity is not clearly known. Herein, we demonstrate that the combination treatment of arsenic trioxide $\left(\mathrm{As}_{2} \mathrm{O}_{3}\right)$ and sulindac resulted in a synergistic augmentation of cytotoxicity toward NCI-H157 lung cancer cells, which was revealed as apoptosis accompanied by chromatin fragmentation and an increase in sub- $\mathrm{G}_{0} / \mathrm{G}_{1}$ fraction. In addition, combination treatment with $\mathrm{As}_{2} \mathrm{O}_{3}$ and sulindac increased the catalytic activity of caspase-3, -8 , and -9 along with induction of Fas/FasL expression and cytosolic release of cytochrome c. Pharmacologic scavenging study of reactive oxygen species (ROS) revealed that synergistic augmentation of cytotoxicity was achieved by generation of ROS, which might modulate the expression of Bcl-2 family proteins, the activity of caspase- 3 , and mitochondrial membrane potential transition.
\end{abstract}

\section{Introduction}

Although many new therapeutic maneuvers have been developed in the treatment of cancers, mortality rates of lung cancer patients are currently high and increasing (1). The 5year survival rate for lung cancer patients with stage IIa disease is $9-25 \%$ and with stage IIIb disease is only 3-7\%. A number of new agents have become available for the treatment of lung cancer, but until now no chemotherapy regimens have offered a significant advantage over others (2). Therefore, new approaches for the treatment of lung cancer are needed. As a complementary therapy, gefitinib, an inhibitor of epidermal

Correspondence to: Dr Raekil Park, Department of Microbiology, Wonkwang University, School of Medicine, 344-2 Shinyong-dong Iksan, Jeonbuk 570-749, South Korea

E-mail: rkpark@wonkwang.ac.kr

Key words: arsenic trioxide, sulindac, apoptosis, lung cancer cell line growth factor receptor tyrosine kinase, and Bevacizumab, a monoclonal antibody directed against vascular endothelial growth factor, were clinically tried with chemotherapy regimens to treat lung cancer patients. However, these combination therapies did not have improved efficacy over chemotherapy regimens alone $(3,4)$.

Arsenic trioxide has long been used as an anticancer agent in traditional Chinese medicine (5) and is currently used in the treatment of refractory and relapsed acute promyelocytic leukemia (APL) without severe marrow suppression (6). Some investigators have reported that $\mathrm{As}_{2} \mathrm{O}_{3}$ induces apoptosis in a variety of human solid tumor cell lines, including carcinomas of the esophagus, stomach, prostate, and ovary as well as neuroblastoma cells (7-10). However, the clinically relevant concentration is a major limiting factor in practical prescription for leukemia patients. The dose range of clinical use is $0.5-$ $2 \mu \mathrm{M}$ of $\mathrm{As}_{2} \mathrm{O}_{3}$ in the treatment of leukemia, whereas there should be over 5-10 $\mu \mathrm{M}$ for induction of apoptotic death in many solid tumor cells. As a consequence, the clinical use and efficacy of $\mathrm{As}_{2} \mathrm{O}_{3}$ have thus far been largely hampered in its universal application to various types of cancer patients, except in patients with APL.

Recently, NSAIDs have attracted much attention after the discovery that sulindac could induce the regression of colon adenomatous polyps in cancer therapy (11). Continuous NSAID administration results in a significant reduction of relative risk for colorectal cancer (12). Sulindac, a structural isoform of indomethacin, exerts antiproliferative and apoptotic effects which eventually lead to the regression of cancer cells $(13,14)$. NSAIDs are known to enhance the cellular responsiveness of tumors toward chemotherapeutic drugs by apoptosis or antiangiogenic effect and are also synergistic with radiotherapy by directly increasing cellular radiation sensitivity as well as inhibiting tumor neovascularization $(15,16)$. In this study, we aimed to investigate whether combination treatment with $\mathrm{As}_{2} \mathrm{O}_{3}$ and sulindac augments their apoptotic potential in NCI-H157 human lung cancer cells.

\section{Materials and methods}

Materials. RPMI-1640, fetal bovine serum (FBS), and antibiotics were obtained from Gibco BRL Co. (Grand Island, 
NY). Arsenic trioxide, sulindac, methylthiazol-2-yl-2,5diphynyl, tetrazolium bromide (MTT), propidium iodide (PI), bicinchoninic acid (BCA), dimethyl sulfoxide (DMSA), n-acetylcysteine (NAC), and glutathione (GSH) were obtained from Sigma Chemical Co. (St. Louis, MO). Antibodies against caspase-3, -8, -9, PARP, ICAD, FAS, FAS/L, Bax, Bid, and Bcl- $\mathrm{x}_{\mathrm{L}}$ were purchased from Santa Cruz Biotechnology (Santa Cruz, CA). JC-1 was obtained from Molecular Probes Co. (Eugene, OR), and antibody against anti-cytochrome c was obtained from Pharmigen Co. (San Diego, CA). Anti-rabbit IgG conjugated horseradish peroxidase antibody and enhanced chemiluminescent (ECL) kit were purchased from Amersham Pharmacia Biotech (Buckinghamshire, UK).

Cell culture and viability test. NCI-H157 human lung cancer cells were obtained from Korean Cell Line Bank (Seoul, Korea) and grown in RPMI-1640 containing 100 units/ml penicillin, $0.1 \mathrm{mg} / \mathrm{ml}$ streptomycin, and $10 \% \mathrm{FBS}$, and maintained in a humidified atmosphere of $5 \% \mathrm{CO}_{2}$ in air at $37^{\circ} \mathrm{C}$ and maintained in log phase. Cell viability was determined by MTT assay. Cells (5x104/well) were seeded in 24-well plates, were added to MTT $(0.5 \mathrm{mg} / \mathrm{ml})$ and kept in a $37^{\circ} \mathrm{C}, 5 \% \mathrm{CO}_{2}$ incubator for an additional $3 \mathrm{~h}$. After three washes of cells with phosphate-buffered saline (PBS, $\mathrm{pH} 7.4$ ), the insoluble formazan product was dissolved in DMSO. Then, the optical density (OD) of each culture well was measured using Microplate reader (Titertek Multiskan, Flow Laboratories, North Ryde, Australia) at $590 \mathrm{~nm}$. The OD of formazan formed in control cells was taken as $100 \%$ of viability and the positivelystained cells with MTT were expressed as the percentage (\%) compared to control cells.

Hoechst 33342 staining. After treatment with reagents, cells were fixed in PBS with $3.7 \%$ paraformaldehyde for $10 \mathrm{~min}$. Cells were washed twice with PBS and then incubated with $10 \mu \mathrm{M}$ Hoechst 33342 (Sigma) in PBS at room temperature for $30 \mathrm{~min}$. After incubation, cell morphology was observed under fluorescence microscope (Leica, Japan).

Flow cytometric analysis. The degree of apoptosis was determined by measuring the number of cells showing below the $\mathrm{G}_{0} / \mathrm{G}_{1}$ phase of DNA content from flow cytometric analysis after staining the cells with propidium-iodide (PI) as originally described by Crissman and Steinkamp (17). Cell cycle analysis was performed with FACScan equipped with Cell Quest software (Becton-Dickinson, San Jose, CA).

Preparation of genomic DNA and electrophoresis. The ladder pattern of DNA strand break was analyzed by agarose gel electrophoresis. Genomic DNA from H157 cells was isolated using a Wizard Genomic DNA purification kit (Promega). After ethanol precipitations, $5 \mu \mathrm{g}$ of DNA was subjected to electrophoresis on $1.5 \%$ agarose for $3 \mathrm{~h}$ at $50 \mathrm{~V}$. DNA was visualized by staining with ethidium bromide under UV light.

Caspase activity assay. To measure caspase activity, whole cell lysate was prepared in a lysis buffer as described previously and used to measure the catalytic activities of caspases (18). Cleavage of fluorogenic substrates, including $100 \mu \mathrm{M} \mathrm{Ac-}$ DEVD-AMC by caspase-3, Ac-IETD-AFC by caspase-8, and
Ac-LEHD-AFC by caspase-9, was measured by spectrofluorometer (Jasco FR-777, Germany) at 380/460 and 405/505 nm, respectively.

Determination of $\mathrm{H}_{2} \mathrm{O}_{2}$ generation. The generation of intracellular $\mathrm{H}_{2} \mathrm{O}_{2}$ was determined as described by Root et al (19) by monitoring the decrease in fluorescence of scopoletin during its oxidation catalyzed by horseradish peroxidase (HRP). H157 cells were harvested and resuspended at $1 \times 10^{6} / \mathrm{ml}$ in PBS without $\mathrm{Ca}^{++}$and $\mathrm{Mg}^{++}$in the presence of $5 \mu \mathrm{M}$ scopoletin and $1 \mathrm{U} / \mathrm{ml} \mathrm{HRP}$ in the dark. Then, cells were added to the wells of the microplate, which was prewarmd at $37^{\circ} \mathrm{C}$ and contained $100 \mu \mathrm{l}$ of reaction mixture with $10 \mu \mathrm{l}$ of buffer. Data were analyzed by flow cytometry (Molecular Devices Co.) with an excitation and emission spectrum of 350 and $460 \mathrm{~nm}$, respectively.

Fluorescent staining of mitochondrial membrane potential transition (MPT). H157 cells $\left(10^{7}\right.$ cells/group) treated with sulindac or $\mathrm{As}_{2} \mathrm{O}_{3}$ were harvested, washed with PBS, and then incubated with $10 \mu \mathrm{g} / \mathrm{ml} \mathrm{JC}-1$ at $37^{\circ} \mathrm{C}$ for $30 \mathrm{~min}$. After incubation, cell morphology was observed at $530 \mathrm{~nm}$ under fluorescence microscope (MPS 60, Leica).

Western blotting. Cell extracts were separated by $10 \%$ SDSPAGE under reduced conditions and transferred onto nitrocellulose membrane. The membrane was blocked with $5 \%$ skim milk in TBS-T (25 mM Tris, $\mathrm{pH} 7.6,138 \mathrm{mM} \mathrm{NaCl}$ and $0.05 \%$ Tween-20) for $1 \mathrm{~h}$ and probed with primary antibodies $(1: 1,000-1: 5,000)$. After a series of washes, the membrane was further incubated with secondary antibody $(1: 2,000-1: 10,000)$ conjugated with horseradish peroxidase (HRP). The immunoreactive signal was detected using an enhanced chemiluminescent (ECL) detection system (Amersham).

Preparation of cytosolic and mitochondrial fractions. Preparation of cytosolic and mitochondrial fractions was performed according to the previous report (20) with some modifications. In brief, $\mathrm{H} 157$ cells were harvested, washed with ice-cold PBS, and then incubated with $500 \mu \mathrm{M}$ of buffer A (250 mM sucrose, $20 \mathrm{mM}$ HEPES pH 7.5, $10 \mathrm{mM}$ $\mathrm{KCl}, 1.5 \mathrm{mM} \mathrm{MgCl}_{2}, 1 \mathrm{mM}$ EGTA, $1 \mathrm{mM}$ EDTA, $1 \mathrm{mM}$ DTT, $1 \mathrm{mM}$ PMSF, $10 \mu \mathrm{g} / \mathrm{ml}$ each of leupeptin, aprotinin and pepstatin A) on ice for $30 \mathrm{~min}$. Then, cells were disrupted by 20 passages through a 26 -gauge needle. The disrupted cells were centrifuged at $750 \mathrm{x}$ g for $10 \mathrm{~min}$. The supernatant was centrifuged at $10000 \mathrm{x}$ g for $25 \mathrm{~min}$. After centrifugation, the cytosolic fraction was frozen at $70^{\circ} \mathrm{C}$. The pellet containing mitochondria was washed with ice-cold buffer A and then resuspended with cell lysis buffer. The resuspended pellet was incubated on ice for $30 \mathrm{~min}$ and then centrifuged at $10000 \mathrm{x} g$ for $25 \mathrm{~min}$. The supernatant was collected as cytosolic fraction of $\mathrm{H} 157$ cells.

Statistical analysis. Each experiment was performed at least three times, and all values are represented as means \pm SD of triplicates. Student's t-test was used to analyze a statistical significance of the results. Values of $\mathrm{p}<0.05$ were considered as statistically significant. 
A

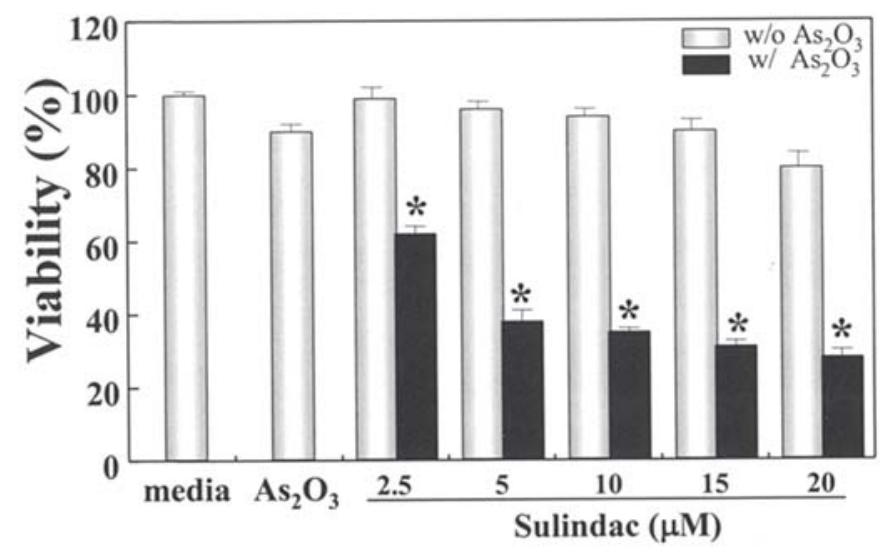

B
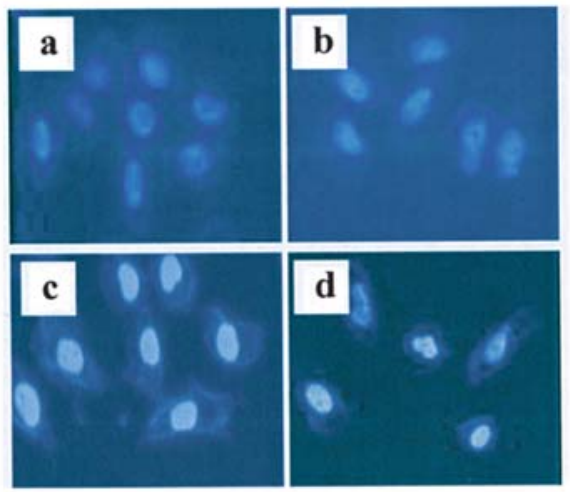

$\mathcal{C}$

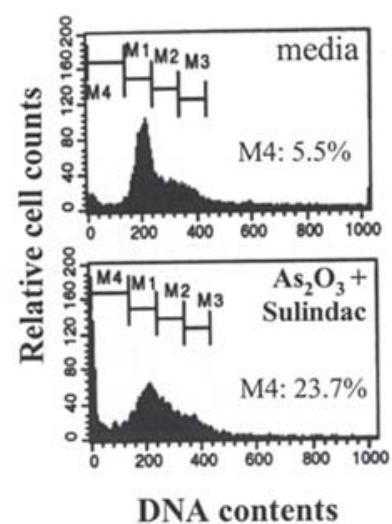

Figure 1. Combination of $\mathrm{As}_{2} \mathrm{O}_{3}$ with sulindac synergistically augmented apoptotic death of $\mathrm{H} 157$ cells. (A) Cells were treated with different concentrations of sulindac in the absence or presence of $2.5 \mu \mathrm{M} \mathrm{As} \mathrm{O}_{3}$ for $48 \mathrm{~h}$ and viability was determined by MTT assay. The data represent the mean \pm SD of three independent experiments. " $\mathrm{p}<0.05$ compared to control. (B) Cells were treated with $\mathrm{As}_{2} \mathrm{O}_{3}(2.5 \mu \mathrm{M})$, sulindac $(5 \mu \mathrm{M})$, or combination of both for $48 \mathrm{~h}$. Then, cells were stained with Hoechst 33342 dye and observed under fluorescent microscope. a, control cells; b, As $\mathrm{O}_{3}$ only; c, sulindac only; d, As $\mathrm{O}_{3}$ and sulindac. (C) Cellular DNA was stained with PI and cell cycle was analyzed by flow cytometry. The data represent one of three independent experiments.

\section{Results}

Combination of $\mathrm{As}_{2} \mathrm{O}_{3}$ with sulindac synergistically augmented apoptotic activity of NCI-H157 cells. To test the synergism in cytotoxicity, NCI-H157 cells were treated with $\mathrm{As}_{2} \mathrm{O}_{3}$ and sulindac and then viability was measured by MTT assay (Fig. 1A). Neither single exposure of $\mathrm{H} 157$ cells to $2.5 \mu \mathrm{M}$ $\mathrm{As}_{2} \mathrm{O}_{3}$ alone nor various concentrations of sulindac alone affected the viability at $48 \mathrm{~h}$. However, combination of $2.5 \mu \mathrm{M}$ $\mathrm{As}_{2} \mathrm{O}_{3}$ with varying doses of sulindac from 2.5 to $20 \mu \mathrm{M}$ resulted in a significant decrease of the viability of $\mathrm{H} 157$ cells in a dose-dependent fashion $(\mathrm{p}<0.05)$. Next, to provide the nature of synergistic cytotoxicity of $\mathrm{As}_{2} \mathrm{O}_{3}$ and sulindac, the phenotypic characteristics of apoptosis were examined. Cells were treated with $2.5 \mu \mathrm{M} \mathrm{As}_{2} \mathrm{O}_{3}$ and $5 \mu \mathrm{M}$ sulindac for 48 h, stained with Hoechst dye 33342, and visualized under fluorescent microscope (Fig. 1B). The nuclei of the control culture as well as of the single-treatment group with $\mathrm{As}_{2} \mathrm{O}_{3}$ and sulindac were an oval round shape with homogenous intensity whereas those of cells simultaneously treated with $\mathrm{As}_{2} \mathrm{O}_{3}$ and sulindac demonstrated a condensed and fragmented shape with irregularity in staining homogeneity. DNA fragmentation by combination treatment with $\mathrm{As}_{2} \mathrm{O}_{3}$ and sulindac was further analyzed as the sub- $\mathrm{G}_{0} / \mathrm{G}_{1}$ fraction of cell cycle analysis by flow cytometry in $\mathrm{H} 157$ cells stained with PI (Fig. 1C). In contrast to the control culture, combination treatment with $\mathrm{As}_{2} \mathrm{O}_{3}$ and sulindac markedly increased the accumulation of the sub- $\mathrm{G}_{0} / \mathrm{G}_{1}$ fraction from $5.5 \%$ to $23.7 \%$, respectively. These data, collectively, indicate that combined treatment with $\mathrm{As}_{2} \mathrm{O}_{3}$ and sulindac may activate apoptotic signaling pathway in $\mathrm{H} 157$ cells.

Combination treatment with $\mathrm{As}_{2} \mathrm{O}_{3}$ and sulindac increased the catalytic activity of caspase-8. The role of death receptor is well known in apoptosis of lung cancer cells after treatment with various chemotherapeutic agents (21). Thus, we first examined whether combination treatment of $\mathrm{As}_{2} \mathrm{O}_{3}$ and sulindac affects the expression of Fas and FasL in H157 cells (Fig. 2A). Cells were treated with $2.5 \mu \mathrm{M} \mathrm{As}_{2} \mathrm{O}_{3}$ and $5 \mu \mathrm{M}$ sulindac for up to $48 \mathrm{~h}$ and lysate was used to carry out Western blotting for Fas and FasL. The date revealed that combination treatment with $\mathrm{As}_{2} \mathrm{O}_{3}$ and sulindac resulted in a marked increase in the expression of Fas and FasL proteins in a time-dependent fashion with the same kinetics. We next measured the catalytic 
A

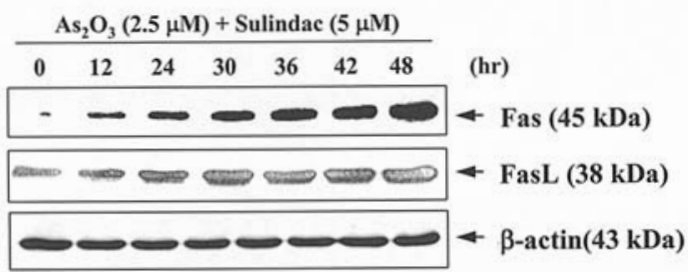

B

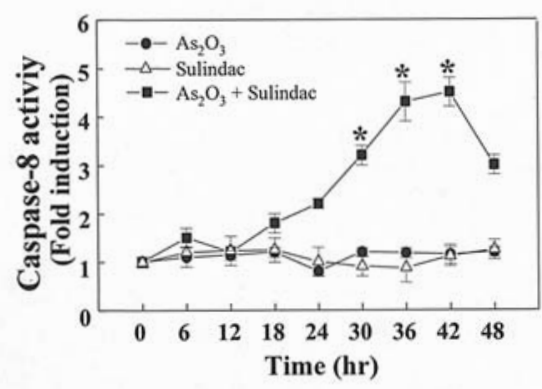

C

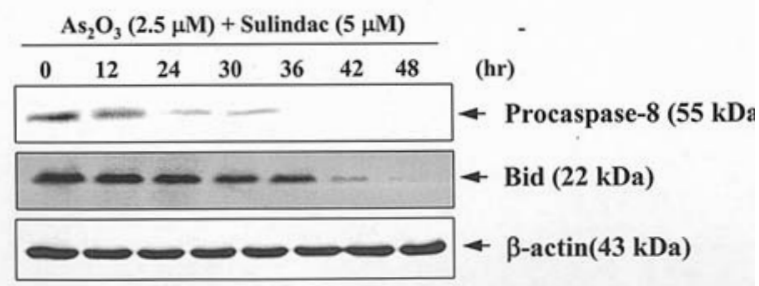

Figure 2. Combination treatment with $\mathrm{As}_{2} \mathrm{O}_{3}$ and sulindac induced the activation of caspase-8. (A) Cells were treated with $2.5 \mu \mathrm{M} \mathrm{As}_{2} \mathrm{O}_{3}$ and $5 \mu \mathrm{M}$ sulindac for $48 \mathrm{~h}$ and lysate was subjected to $12.5 \%$ SDS-PAGE to measure the expression of Fas and FasL proteins. (B) After treatment of cells with $\mathrm{As}_{2} \mathrm{O}_{3}(2.5 \mu \mathrm{M})$ only, sulindac $(5 \mu \mathrm{M})$ only, or combination of both for up to $48 \mathrm{~h}$, lysate was used to measure the catalytic activity of caspase- 8 by using a fluorogenic substrate. The data represent the mean \pm SD of triplicate experiments. ${ }^{*} \mathrm{p}<0.05$. (C) Lysate was used to measure the expression of procaspase- 8 and Bid protein.

activity of caspase-8, a downstream target of Fas/FasL, in cells treated with $\mathrm{As}_{2} \mathrm{O}_{3}$ and sulindac for $48 \mathrm{~h}$ (Fig. 2B). The enzymatic activity of caspase- 8 started to increase at $18 \mathrm{~h}$, attained its peak at 36-42 h, and subsequently decreased in cells treated with $\mathrm{As}_{2} \mathrm{O}_{3}$ and sulindac. However, single application with either $\mathrm{As}_{2} \mathrm{O}_{3}$ or sulindac did not affect the catalytic activity of caspase- 8 in cells. Consistent with the enzymatic activity, the expression level of pro-caspase- 8 was decreasing at $24 \mathrm{~h}$ and was undetectable at $36 \mathrm{~h}$ after combination treatment with $\mathrm{As}_{2} \mathrm{O}_{3}$ and sulindac. Furthermore, a time-dependent study of Bid expression demonstrated that Bid expression was gradually decreased by combination treatment with $\mathrm{As}_{2} \mathrm{O}_{3}$ and sulindac (Fig. 2C). These data indicate that combination treatment with $\mathrm{As}_{2} \mathrm{O}_{3}$ and sulindac activates the signaling pathway of extrinsic caspase, including Fas/FasL, caspase-8, and Bid truncation, which may target mitochondrial dysfunction.

Combination treatment with $\mathrm{As}_{2} \mathrm{O}_{3}$ and sulindac increased the catalytic activity of caspase- 9 . To confirm the implication of intrinsic caspase cascade, including caspase-9, in apoptotic signaling of $\mathrm{H} 157$ cells after combination treatment with $\mathrm{As}_{2} \mathrm{O}_{3}$ and sulindac, cells were subjected to the catalytic activity
A

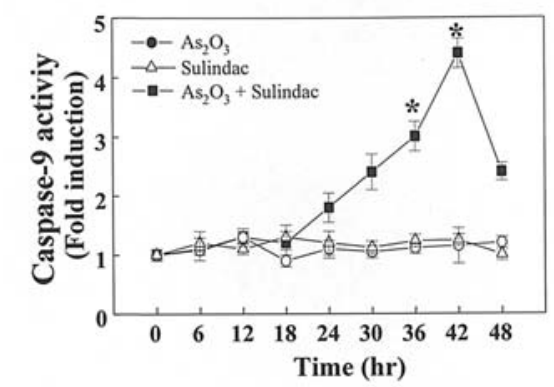

B

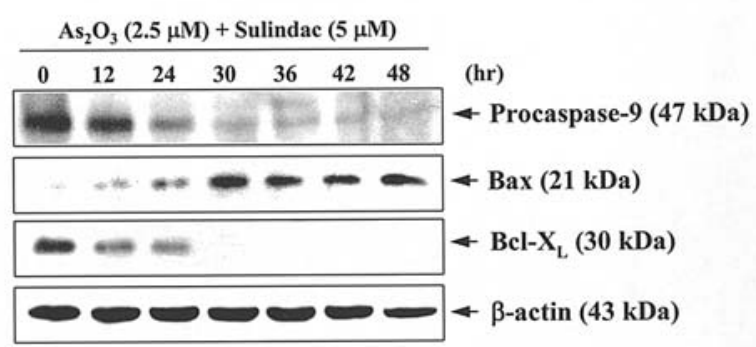

C

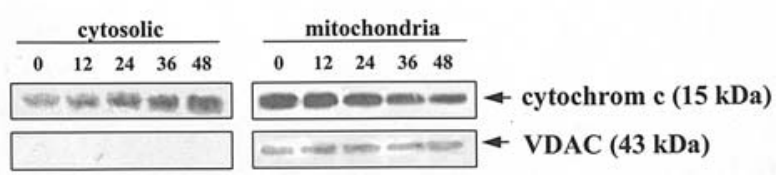

Figure 3. Combination treatment with $\mathrm{As}_{2} \mathrm{O}_{3}$ and sulindac induced the activation of caspase-9. (A) Cells were treated with $\mathrm{As}_{2} \mathrm{O}_{3}(2.5 \mu \mathrm{M})$ only, sulindac $(5 \mu \mathrm{M})$ only, or combination of both for up to $48 \mathrm{~h}$, lysate was used to measure the catalytic activity of caspase- 9 by using a fluorogenic substrate. The data represent the mean $\pm \mathrm{SD}$ of triplicate experiments. ${ }^{*} \mathrm{p}<0.05$. (B) Cells were treated with $2.5 \mu \mathrm{M} \mathrm{As}_{2} \mathrm{O}_{3}$ and $5 \mu \mathrm{M}$ sulindac for $48 \mathrm{~h}$ and lysate was subjected to $12.5 \%$ SDS-PAGE to measure the expression of pro-caspase-9, Bax, and $\mathrm{Bcl}-\mathrm{X}_{\mathrm{L}}$. (C) Lysate was fractionated into cytosolic and mitochondrial portions and proteins were separated on 15\% SDS-PAGE to immunoblot for cytochrome c. The purity of the mitochondrial fraction was determined with anti-VDAC antibody.

assay for caspase-9 (Fig. 3A). Also, activation of caspase-9 was further confirmed by a gradual decrease in expression level of pro-caspase- 9 according to time after combination treatment with $\mathrm{As}_{2} \mathrm{O}_{3}$ and sulindac.

We were further interested in the expression of anti- or pro-apoptogenic Bcl-2 family proteins, which is known to affect mitochondrial functions (Fig. 3B) as a downstream modulator of caspase. Combination treatment with $\mathrm{As}_{2} \mathrm{O}_{3}$ and sulindac resulted in a gradual increase of pro-apoptogenic Bcl-2 protein whereas it decreased the level of anti-apoptogenic $\mathrm{Bcl}-\mathrm{X}_{\mathrm{L}}$ in a time-dependent fashion. This result led us to test whether mitochondrial dysfunction occurred in $\mathrm{H} 157$ cells treated with $2.5 \mu \mathrm{M} \mathrm{As}_{2} \mathrm{O}_{3}$ and $5 \mu \mathrm{M}$ sulindac for $48 \mathrm{~h}$. Thus, the cell lysate was fractionated into mitochondrial and cytosolic parts, which were used to measure the expression of cytochrome c by Western blotting (Fig. 3C). Cytochrome $\mathrm{c}$ in the cytosolic fraction was markedly increased at $48 \mathrm{~h}$ whereas mitochondrial cytochrome $\mathrm{c}$ was time-dependently diminished in expression. The purity of mitochondrial fraction was verified by Western blotting with anti-VDAC antibody. 
A

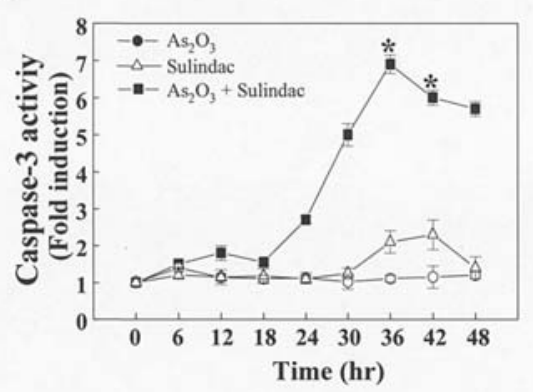

B

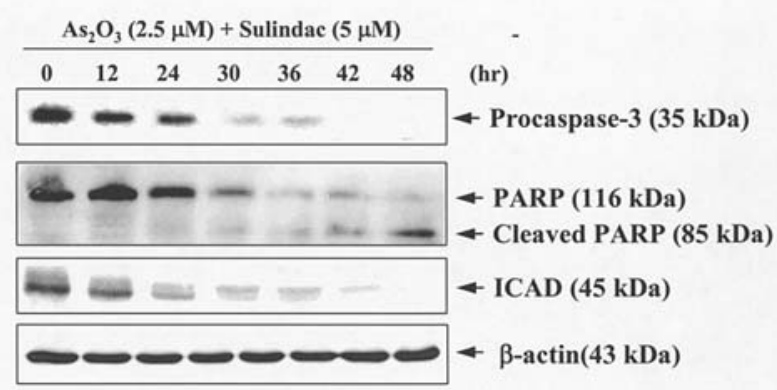

Figure 4. Combination treatment with $\mathrm{As}_{2} \mathrm{O}_{3}$ and sulindac induced the activation of caspase-3. (A) Cells were treated with $\mathrm{As}_{2} \mathrm{O}_{3}(2.5 \mu \mathrm{M})$ only, sulindac $(5 \mu \mathrm{M})$ only, or combination of both for up to $48 \mathrm{~h}$. Lysate was used to measure the catalytic activity of caspase- 3 by using a fluorogenic substrate. The data represent the mean \pm SD of triplicate. ${ }^{*} \mathrm{p}<0.05$. (B) Cells were treated with $2.5 \mu \mathrm{M} \mathrm{As}_{2} \mathrm{O}_{3}$ and $5 \mu \mathrm{M}$ sulindac for $48 \mathrm{~h}$ and lysate was subjected to $12.5 \%$ SDS-PAGE to measure the expression of pro-caspase-3, PARP, and ICAD.

Combination treatment with $\mathrm{As}_{2} \mathrm{O}_{3}$ and sulindac increased the catalytic activity of caspase-3. To gain the downstream event of activation of caspases, including caspase- 8 and -9, $\mathrm{H} 157$ cells were treated with $2.5 \mu \mathrm{M} \mathrm{As}_{2} \mathrm{O}_{3}$ and $5 \mu \mathrm{M}$ sulindac for up to $48 \mathrm{~h}$, and the proteolytic activity of caspase- 3 was determined (Fig. 4A). The enzymatic activation of caspase-3 started after $24 \mathrm{~h}$, attained its peak at $36 \mathrm{~h}$, and was sustained at that level for $48 \mathrm{~h}$ in cells treated with $\mathrm{As}_{2} \mathrm{O}_{3}$ and sulindac. However, single application with either $\mathrm{As}_{2} \mathrm{O}_{3}$ or sulindac did not affect the catalytic activity of caspase- 3 of H157 cells. To further confirm the activation of caspase-3, the cleavage of pro-caspase-3 and intracellular biosubstrates, including PARP and ICAD, was measured by Western blot analysis (Fig. 4B). Degradation of pro-caspase- 3 by combination treatment with $2.5 \mu \mathrm{M} \mathrm{As} \mathrm{O}_{3}$ and $5 \mu \mathrm{M}$ sulindac occurred at $30 \mathrm{~h}$ and the immunoreactive band was hardly detectible $42 \mathrm{~h}$ after treatment. Cleavage of PARP from 116 to $85 \mathrm{kDa}$ was clearly demonstrated at $30 \mathrm{~h}$ after combination treatment with $\mathrm{As}_{2} \mathrm{O}_{3}$ and sulindac. Also, ICAD expression started to decrease at $24 \mathrm{~h}$ in a time-dependent manner by combination treatment with $\mathrm{As}_{2} \mathrm{O}_{3}$ and sulindac.

Antioxidants antagonized the synergistic cytotoxicity of $\mathrm{As}_{2} \mathrm{O}_{3}$ and sulindac in $\mathrm{H} 157$ cells. To investigate the synergistic mechanism of $\mathrm{As}_{2} \mathrm{O}_{3}$ and sulindac, we tested the effect of antioxidants, including NAC and GSH, in H157 cells. Cells were pretreated with either NAC or GAH, followed by the addition of $2.5 \mu \mathrm{M} \mathrm{As}_{2} \mathrm{O}_{3}$ and $5 \mu \mathrm{M}$ sulindac for $48 \mathrm{~h}$, and
A
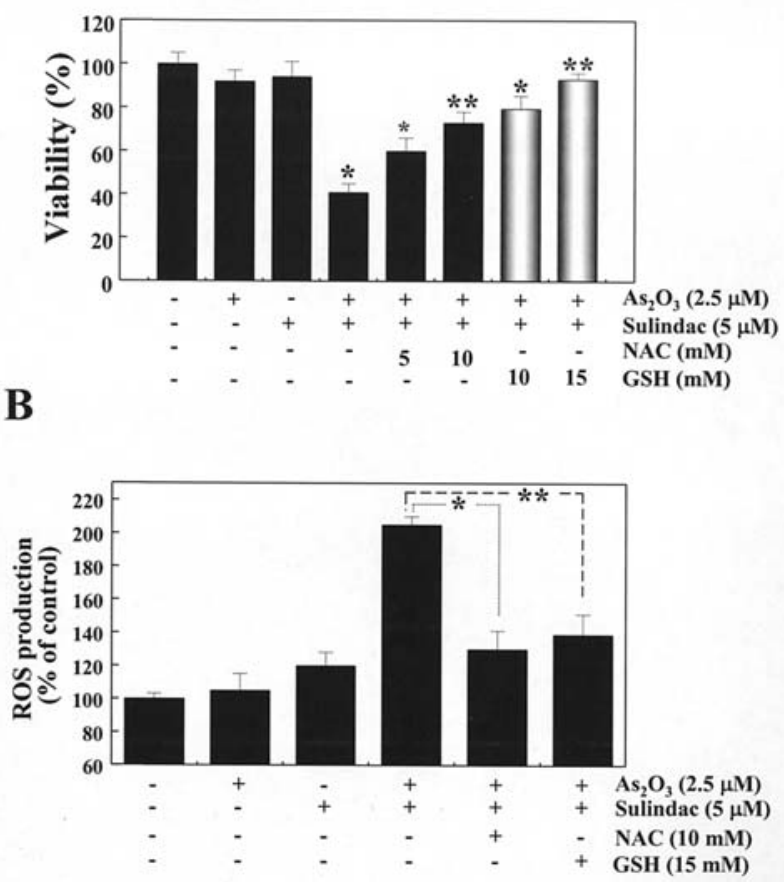

C

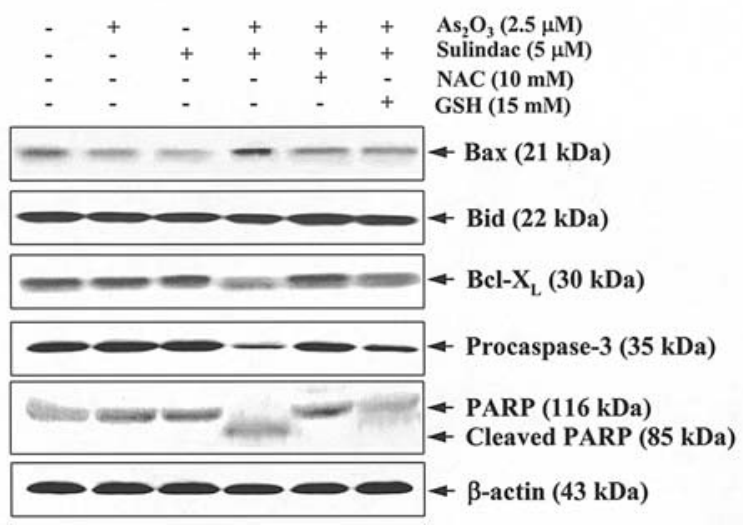

Figure 5. Antioxidants antagonized the synergistic cytotoxicity of $\mathrm{As}_{2} \mathrm{O}_{3}$ and sulindac in $\mathrm{H} 157$ cells. Cells were pretreated with GSH or NAC, followed by the addition of $\mathrm{As}_{2} \mathrm{O}_{3}$, sulindac, or combination of both for $48 \mathrm{~h}$. (A) Cell viability was determined by MTT assay. ${ }^{*} \mathrm{p}<0.05 ;{ }^{* * *} \mathrm{p}<0.01$. (B) Measurement of intracellular $\mathrm{H}_{2} \mathrm{O}_{2}$ was determined fluorimetrically using scopoletinhorseradish peroxidase assay. The data represent the mean $\pm \mathrm{SD}$ of three independent experiments. ${ }^{*} \mathrm{p}<0.05 ;{ }^{* *} \mathrm{p}<0.01$. (C) Under the same experimental conditions, lysate was subjected to $12.5 \%$ SDS-PAGE to measure the expression of Bax, Bid, Bcl- $\mathrm{X}_{\mathrm{L}}$. pro-caspase-3, and PARP.

viability was measured by MTT assay. As shown in previous data, combination treatment with $\mathrm{As}_{2} \mathrm{O}_{3}$ and sulindac resulted in a significant decrease in cell viability ( $58 \%$ of control cells) even though single application of either one did not exert any notable change in cell viability. However, pretreatment with either NAC or GSH significantly inhibited the synergistic cytotoxicity of $\mathrm{As}_{2} \mathrm{O}_{3}$ and sulindac in a dose-dependent manner (Fig. 5A). To verify the direct involvement of reactive oxygen species (ROS), we measured the generation of intracellular hydrogen peroxide $\left(\mathrm{H}_{2} \mathrm{O}_{2}\right)$ by scopoletin-horseradish peroxidase (HRP) assay (Fig. 5B). The data revealed that combination treatment with $\mathrm{As}_{2} \mathrm{O}_{3}$ and sulindac induced the 

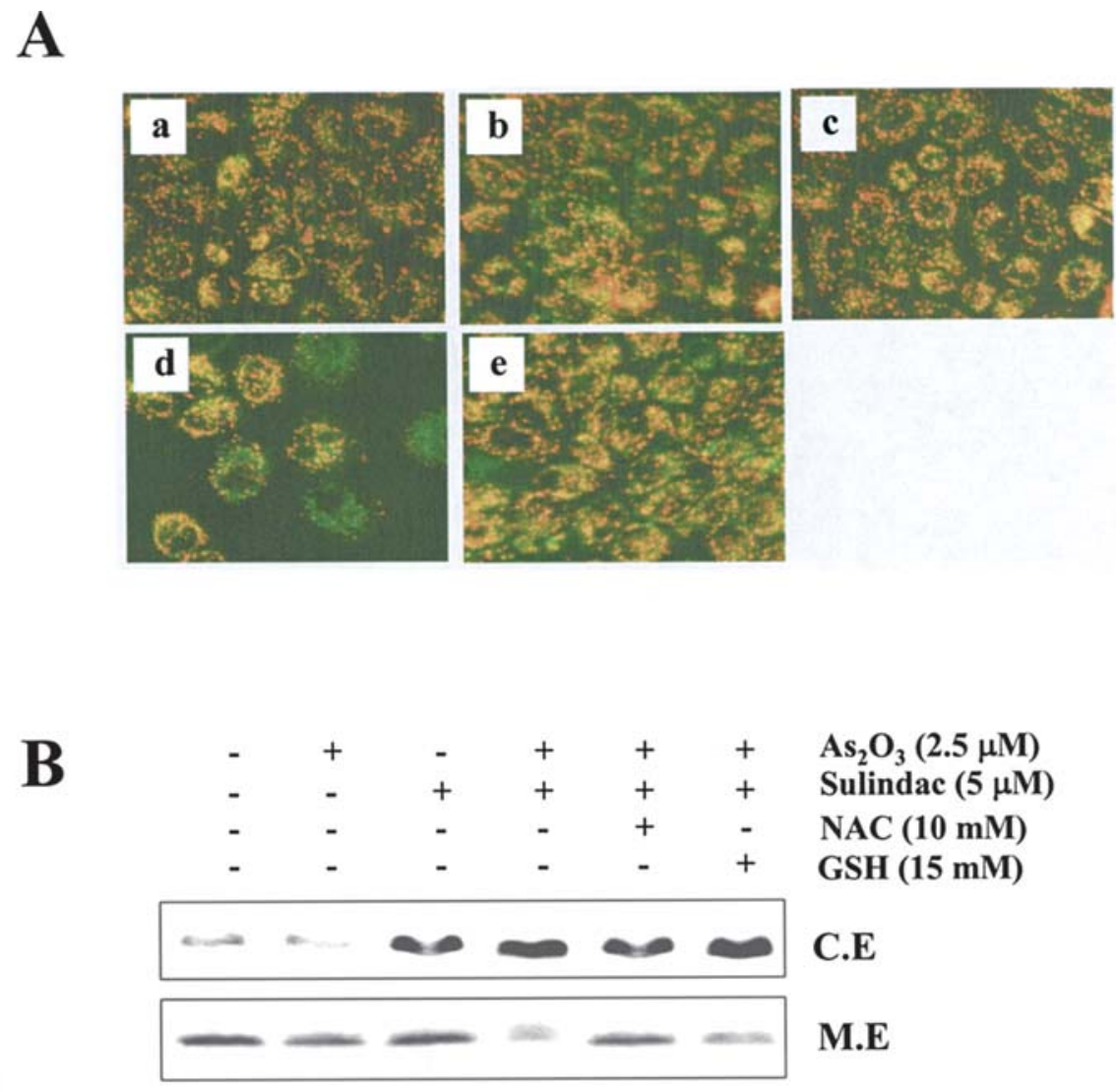

\author{
$\mathrm{As}_{2} \mathrm{O}_{3}(2.5 \mu \mathrm{M})$ \\ Sulindac $(5 \mu \mathrm{M})$ \\ NAC $(10 \mathrm{mM})$ \\ GSH (15 mM)
}

C.E

M.E

\title{
Anti-cytochrome c blot
}

Figure 6. Antioxidants prevented the mitochondrial membrane potential transition (MPT) and cytosolic release of cytochrome c by combination treatment with $\mathrm{As}_{2} \mathrm{O}_{3}$ and sulindac. (A) Cells were treated with $\mathrm{As}_{2} \mathrm{O}_{3}$ and/or sulindac in the presence or absence of antioxidants, including NAC and GSH. Then, cells were stained with $10 \mu \mathrm{g} / \mathrm{ml}$ of JC-1 and observed under fluorescent microscope. a, control cells; b, $\mathrm{As}_{2} \mathrm{O}_{3}$ only; c, sulindac only; $\mathrm{d}, \mathrm{As}_{2} \mathrm{O}_{3}$ and sulindac; e, pretreatment of GSH plus $\mathrm{As}_{2} \mathrm{O}_{3}$ and sulindac. (B) Cells were treated with $\mathrm{As}_{2} \mathrm{O}_{3}$ and/or sulindac in the presence or absence of antioxidants. Lysate was fractionated into cytosolic and mitochondrial portions and proteins were separated on 15\% SDS-PAGE to immunoblot for cytochrome c.

generation of $\mathrm{H}_{2} \mathrm{O}_{2}$ (2-fold), which returned to the level of that in control cells by pretreatment with antioxidants, including NAC and GSH.

To further confirm the implication of signaling components of apoptosis, cell lysate was used to perform Western blot analysis. Combination treatment with $\mathrm{As}_{2} \mathrm{O}_{3}$ and sulindac induced the expression of apoptogenic Bax whereas it resulted in a decrease in anti-apoptotic Bid and $\mathrm{Bcl}_{\mathrm{L}}$ (Fig. 5C). Combination treatment with $\mathrm{As}_{2} \mathrm{O}_{3}$ and sulindac had no influence on the expression level of Bcl-2 (data not shown). However, the expression levels of Bax, Bid, and $\mathrm{Bcl}-\mathrm{X}_{\mathrm{L}}$ were demonstrated as similar to that of control cells in cells pretreated with NAC and GSH before combination treatment with $\mathrm{As}_{2} \mathrm{O}_{3}$ and sulindac. We next measured the effect of antioxidants on the activation of caspase-3. Pretreatment of antioxidants, including NAC and GSH, markedly suppressed the activation of caspase-3, evidenced by the decreased expression of pro-caspase- 3 and cleavage of PARP in cells treated with $\mathrm{As}_{2} \mathrm{O}_{3}$ and sulindac.

Pretreatment of antioxidants prevented mitochondrial dysfunction by combination treatment with $\mathrm{As}_{2} \mathrm{O}_{3}$ and sulindac. To examine the upstream component of caspase- 3 in apoptosis signaling, markers of mitochondrial dysfunction, including mitochondrial membrane potential transition (MPT) and cytosolic release of cytochrome c, were evaluated in cells treated with $\mathrm{As}_{2} \mathrm{O}_{3}$ and sulindac. Cells were treated with $2.5 \mu \mathrm{M} \mathrm{As}_{2} \mathrm{O}_{3}$ and $5 \mu \mathrm{M}$ sulindac for $48 \mathrm{~h}$ in the presence or absence of antioxidants, including $10 \mathrm{mM}$ NAC and $15 \mathrm{mM}$ GSH. Then, cells were used to measure the MPT by staining mitochondria with JC-1 under a fluorescence microscope. Mitochondria were mainly located in the cytosol as a punctuated form colored with orange in the control culture (Fig. 6A, a) and cells treated with $\mathrm{As}_{2} \mathrm{O}_{3}$ alone (Fig. 6A, b) and sulindac alone (Fig. 6A, c). Simultaneous exposure of $\mathrm{H} 157$ cells to $\mathrm{As}_{2} \mathrm{O}_{3}$ and sulindac caused a dramatic change in MPT, shown as a diffuse form and mainly located in the cytosol as well as the nuclei (Fig. 6A, d). However, pretreatment of GSH prevented the changes in MPT and morphological features as similarly demonstrated in control cells (Fig. 6A, e). To provide further evidence of mitochondrial dysfunction, cytosolic release of cytochrome c was examined by Western blotting in both mitochondrial and cytosolic fractions (Fig. 6B). Cytochrome $\mathrm{c}$ in the cytosolic fraction was markedly increased in cells treated with sulindac only as well as with combination treatment of both. Consistently, the immunoreactive band of cytosolic cytochrome $\mathrm{c}$ in cells pretreated with either NAC or GSH remained at a similar level in its intensity to 
that of control cells. The purity of mitochondrial fraction was verified by Western blotting with anti-VDAC antibody.

\section{Discussion}

NSAIDs are known to enhance tumor cell responses toward various anticancer therapies, including biologic therapy, radiotherapy, and conventional anticancer chemotherapeutic agents. A combination of sulindac and EKI-569, an inhibitor of EGFR tyrosine kinase, remarkably protects intestinal cells from neoplastic transformation (22). NSAIDs also significantly increase the cytotoxicity of anthracyclines and vinca alkaloids in human lung cancer cells and leukemia cell lines (23). The combination of sulindac with paclitaxel and/or cisplatin afforded a synergistic augmentation of cytotoxicity toward lung cancer cell lines (24). In addition, sulindac enhanced cytotoxicity when combined with $\mathrm{As}_{2} \mathrm{O}_{3}$ in A549 human lung cancer cells, but the exact mechanism of synergism was not clearly defined (25).

Although $\mathrm{As}_{2} \mathrm{O}_{3}$ is known to be effective in the treatment of leukemic cells, especially in APL, there is little evidence of its pharmacologic efficacy in solid tumor cells. Bode and Dong demonstrated that $\mathrm{As}_{2} \mathrm{O}_{3}$ induced apoptosis of cancer cells through the consequences of oxidative stress, activation of caspase pathways, and mitochondrial dysfunction (26). Arsenic trioxide directly condenses mitochondrial matrix and decreases mitochondrial transmembrane potential (MMP) to trigger apoptosis via the release of cytochrome $\mathrm{c}$ from mitochondria and the subsequent activation of the caspase proteins $(27,28)$. Also, treatment of $\mathrm{As}_{2} \mathrm{O}_{3}$ results in reduction of $\mathrm{GSH}$ and thereby increases the intracellular ROS level in certain APL cells (29).

In this study, we showed that combination treatment with $\mathrm{As}_{2} \mathrm{O}_{3}$ and sulindac enhanced the activity of intrinsic and extrinsic caspase cascades through ROS generation. Furthermore, combination treatment also resulted in loss of MMP, changes in expression of Bcl-2 family proteins and cytosolic release of cytochrome c. Mitochondria are known as an important regulator of apoptosis (30). It undergoes a series of consequence changes during apoptotic death of cells. A loss of MMP together with the permeability transition pore induces the cytosolic release of cytochrome $\mathrm{c}$, which further activates caspase-3, following activation of caspase-9. In accordance with previous reports of apoptosis signaling, our data demonstrated that combination treatment resulted in perturbation of mitochondrial functions in $\mathrm{H} 157$ cells.

Recent evidence suggests that sulindac engages the mitochondrial pathway involving caspase- 9 and Bax in induction of apoptotic effects. Similarly, $\mathrm{As}_{2} \mathrm{O}_{3}$ can induce apoptosis via upregulation of intracellular $\mathrm{ROS}$, such as $\mathrm{H}_{2} \mathrm{O}_{2}$, which cause depolarization of the mitochondrial transmembrane and subsequent caspase- 3 activation. These pathways may account for the interactions between $\mathrm{As}_{2} \mathrm{O}_{3}$ and sulindac in our experimental model. The molecular mechanism of synergism in the combination of $\mathrm{As}_{2} \mathrm{O}_{3}$ and sulindac was involved in the generation of ROS because the apoptotic death of $\mathrm{H} 157$ cells by combination treatment was inhibited by scavenging $\mathrm{H}_{2} \mathrm{O}_{2}$ with NAC and GSH, consequently restoring the MPT, which preceded the caspase- 3 activation, DNA fragmentation, and morphologic features of apoptosis.
Consistent with the report of Finucane et al (31), we also speculate that the induction of apoptogenic Bcl-2 family protein, such as Bax, together with decreased levels of antiapoptogenic Bcl-2 family protein, such as Bid and Bcl- $\mathrm{X}_{\mathrm{L}}$, may contribute the release of cytochrome $\mathrm{c}$ and generation of ROS in $\mathrm{H} 157$ cells treated with $\mathrm{As}_{2} \mathrm{O}_{3}$ and sulindac. Single treatment with sulindac could induce the cytosolic release of cytochrome c even though the MPT was not changed at all. This result may indicate the possibility that MPT is not always required for cytosolic release of cytochrome $\mathrm{c}$ or that cytosolic release of cytochrome $\mathrm{c}$ is not only a limiting condition for caspase- 3 activation, followed by formation of apoptosome complex.

Up to 10-fold higher concentrations of $\mathrm{As}_{2} \mathrm{O}_{3}$ are required to induce apoptosis in non-APL tumor cells, which is generally unacceptable in the clinic because of higher toxicity. As a consequence, clinical use of $\mathrm{As}_{2} \mathrm{O}_{3}$ has thus far been largely limited to patients with APL. Our data suggest that combination treatment with $\mathrm{As}_{2} \mathrm{O}_{3}$ and sulindac may be useful in practical application in the treatment of solid tumors, including lung cancer, as an alternate anticancer strategy for circumventing the serious general toxicity of anticancer chemotherapeutic agents, such as $\mathrm{As}_{2} \mathrm{O}_{3}$.

\section{Acknowledgements}

This study was supported by a grant from Wonkwang University in 2005.

\section{References}

1. Jemal A, Chu KC and Tarone RE: Recent trends in lung cancer mortality in the United States. J Natl Cancer Inst 93: 277-283, 2001

2. Schiller JH, Harrington D, Belani CP, Langer C, Sandler A, Krook J, Zhu J and Johnson DH: Comparison of four chemotherapy regimens for advanced non-small-cell lung cancer. $\mathrm{N}$ Engl J Med 346: 92-98, 2002.

3. Giaccone G, Herbst RS, Manegold C, Scagliotti G, Resell R, Miller V, Natale RB, Schiller JH, von Pawel J, Pluzanska A, Gatzemeier U, Grous J, Ochs JS, Averbuch SD, Wolf MK, Rennie P, Fandi A and Johnson DH: Gefitinib in combination with gemcitabine and cisplatin in advanced non-small-cell lung cancer: a phase III trial-INTACT 1. J Clin Oncol 22: 777-784, 2004

4. Sandler AB, Johnson DH and Herbst RS: Anti-vascular endothelial growth factor monoclonals in non-small cell lung cancer. Clin Cancer Res 10: 4258-4262, 2004.

5. Antman KH: Introduction: the history of arsenic trioxide in cancer therapy. Oncologist 6: 1-2, 2001.

6. Shen ZX, Chen GQ, Ni JH, Li XS, Xiong SM, Qiu QY, Zhu J, Tang W, Sun GL, Yang KQ, Chen Y, Zhou L, Fang ZW, Wang YT, Ma J, Zhang P, Zhang TD, Chen SJ, Chen Z and Wang ZY: Use of arsenic trioxide $\left(\mathrm{As}_{2} \mathrm{O}_{3}\right)$ in the treatment of acute promyelocytic leukemia (APL): II, clinical efficacy and pharmacokinetics in relapsed patients. Blood 89: 3354-3360, 1997.

7. Shen ZY, Tan LJ, Cai WJ, Shen J, Chen C, Tang XM and Zheng MH: Arsenic trioxide induces apoptosis of oesophageal carcinoma in vitro. Int J Mol Med 4: 33-37, 1999.

8. Zhang TC, Cao EH, Li JF, Ma W and Qin JF: Induction of apoptosis and inhibition of human gastric cancer MGC-803 cell growth by arsenic trioxide. Eur J Cancer 35: 1258-1263, 1999.

9. Uslu R, Sanli UA, Sezgin C, Karabulut B, Terzioglu E, Omay SB and Goker E: Arsenic trioxide-mediated cytotoxicity and apoptosis in prostate and ovarian carcinoma cell lines. Clin Cancer Res 6: 4957-4964, 2000.

10. Akao Y, Nakagawa Y and Akiyama K: Arsenic trioxide induces apoptosis in neuroblastoma cell lines through the activation of caspase 3 in vitro. FEBS Lett 445: 59-62, 1999. 
11. Giardiello FM, Spannhake EW, DuBois RN, Hylind LM, Robinson CR, Hubbard WC, Hamilton SR and Yang VW: Prostaglandin levels in human colorectal mucosa: effects of sulindac in patients with familial adenomatous polyposis. Dig Dis Sci 43: 311-316, 1998.

12. Shiff SJ and Rigas B: Non-steroidal anti-inflammatory drugs and colorectal cancer: evolving concepts of their chemopreventive actions. Gastroenterology 113: 1992-1998, 1997.

13. Shiff SJ, Qiao L, Tsai LL and Rigas B: Sulindac sulfide, an aspirin-like compound, inhibits proliferation, causes cell cycle quiescence, and induces apoptosis in HT-29 colon adenocarcinoma cells. J Clin Invest 96: 491-503, 1995.

14. Chan TA, Morin PJ, Vogelstein B and Kinzler KW: Mechanism underlying non-steroidal antiinflammatory drug-mediated apoptosis. Proc Natl Acad Sci USA 95: 681-686, 1998.

15. Milas L: Cyclooxygenase-2 (COX-2) enzyme inhibitors as potential enhancers of tumor radioresponse. Semin Radiat Oncol 11: 290-299, 2001.

16. Koki AT, Leahy KM and Masferrer JL: Potential utility of COX-2 inhibitors in chemoprevention and chemotherapy. Expert Opin Invest Drugs 8: 1623-1638, 1999.

17. Crissman HA and Steinkamp JA: Cell cycle-related changes in chromatin structure detected by flow cytometry using multiple DNA fluorochromes. Eur J Histochem 37: 129-138, 1993.

18. Kim MS, So HS, Lee KM, Park JS, Lee JH, Moon SK, Ryu DG, Chung SY, Jung BH, Kim YK, Moon G and Park R: Activation of caspase cascades in Korean mistletoe (Viscum album var. coloratum) lectin-II-induced apoptosis of human myeloleukemic U937 cells. Gen Pharmacol 34: 349-355, 2000.

19. Root RK, Metcalf J, Oshino N and Chance B: $\mathrm{H}_{2} \mathrm{O}_{2}$ release from human granulocytes during phagocytosis. I. Documentation, quantitation, and some regulating factors. J Clin Invest 55: 945-955, 1975

20. Wolf CM and Eastman A: The temporal relationship between protein phosphatase, mitochondrial cytochrome c release. Exp Cell Res 247: 505-513, 1999.

21. Fokkema E, Groen HJ, Meijer C, Timens W, De Jong S and De Vries EG: The role of apoptosis-related genes in non-smallcell lung cancer. Clin Lung Cancer 4: 174-182, 2002.
22. Torrance CJ, Jackson PE, Montgomery E, Kinzler KW, Vogelstein B, Wissner A, Nunes M, Frost P and Discafani CM: Combinatorial chemoprevention of intestinal neoplasia. Nat Med 6: 1024-1028, 2000.

23. Duffy CP, Elliott CJ, O'Connor RA, Heenan MM, Coyle S, Cleary IM, Kavanagh K, Verhaegen S, O'Loughlin CM, NicAmhlaoibh R and Clynes M: Enhancement of chemotherapeutic drug toxicity to human tumour cells in vitro by a subset of NSAIDs. Eur J Cancer 34: 1250-1259, 1998.

24. Soriano AF, Helfrich B, Chan DC, Heasley LE, Bunn PA Jr and Chou TC: Synergistic effects of new chemopreventive agents and conventional cytotoxic agents against human lung cancer cell lines. Cancer Res 59: 6178-6184, 1999.

25. Jiang TT, Brown SL and Kim JH: Combined effect of arsenic trioxide and sulindac sulfide in A549 human lung cancer cells in vitro. J Exp Clin Cancer Res 23: 259-262, 2004.

26. Bode AM and Dong Z: The paradox of arsenic: molecular mechanisms of cell transformation and chemotherapeutic effects. Crit Rev Oncol Hematol 42: 5-24, 2002.

27. Cai X, Shen YL, Zhu Q, Jia PM, Yu Y, Zhou L, Huang Y, Zhang JW, Xiong SM, Chen SJ, Wang ZY, Chen Z and Chen GQ: Arsenic trioxide-induced apoptosis and differentiation are associated respectively with mitochondrial transmembrane potential collapse and retinoic acid signaling pathways in acute promyelocytic leukemia. Leukemia 14: 262-270, 2000

28. Woo SH, Park IC, Park MJ, Lee HC, Lee SJ, Chun YJ, Lee SH, Hong SI and Rhee CH: Arsenic trioxide induces apoptosis through a reactive oxygen species-dependent pathway and loss of mitochondrial membrane potential in HeLa cells. Int J Oncol 21: $57-63,2002$.

29. Dai J, Weinberg RS, Waxman S and Jing Y: Malignant cells can be sensitized to undergo growth inhibition and apoptosis by arsenic trioxide through of the glutathione redox system. Blood 93: 268-277, 1999.

30. Green DR and Reed JC: Mitochondria and apoptosis. Science 281: 1309-1312, 1998.

31. Finucane DM, Bossy-Wetzel E, Waterhouse NJ, Cotter TG and Green DR: Bax induces caspases activation and apoptosis via cytochrome c release from the mitochondria is inhibitable by Bcl-xL. J Biol Chem 274: 2225-2233, 1999. 